\title{
Landslides and floods zonation using geomorphological analyses in a dynamic catchment of Costa Rica
}

\section{Zonificación de deslizamientos e inundaciones usando análisis geomorfológicos en una cuenca dinámica de Costa Rica}

\author{
Adolfo Quesada-Román?
}

Recibido 4 de noviembre de 2020; aceptado 29 de diciembre 2020

\begin{abstract}
During the last decades, the number of floods and landslides events have been growing every year in Costa Rica, both in urban and rural areas. Despite of the geomorphological diversity of Central America and Costa Rica, there are few detailed geomorphological studies in the region. A 1:25,000 geomorphological analyses of the Upper General River Catchment (UGRC) located in the southeast in Costa Rica is presented, based on the interpretation of aerial photographs and field geomorphological mapping. First, a morphometric analysis was performed to calculate and analyze seven variables that were merged in order to produce the flood and landslides susceptibility maps. Second, a total of 43 types of landforms divided genetically into endogenic (tectonic), and exogenic (fluvial, gravitational, and glacial) features are mapped for an area of $1560 \mathrm{~km}^{2}$. Finally, a geomorphological hazard map with the zonation of the different susceptibility levels of landslides and floods were performed. This cartography is important in terms of geomorphological evolution, disaster risk reduction as well as for land use planning for approximately 40,000 inhabitants. The presented methodology can also be applied in other developing countries for different purposes such as landscape evolution, morphogenetic detailed maps, disaster risk reduction, and land use planning.
\end{abstract}

Key words: geomorphology, natural hazards, geomorphometry, geomorphological mapping, disaster risk reduction. 


\section{RESUMEN}

Durante las últimas décadas, el número de inundaciones y deslizamientos han ido creciendo cada año en Costa Rica, tanto en las zonas urbanas como en las rurales. A pesar de la diversidad geomorfológica de Centroamérica y Costa Rica, existen pocos estudios geomorfológicos detallados en la región. Se presenta un análisis geomorfológico 1: 25,000 de la Cuenca del Río General Superior (CRGS) ubicada en el sureste de Costa Rica, basado en la interpretación de fotografías aéreas y mapeo geomorfológico de campo. Primero, se realizó un análisis geomorfométrico para calcular y analizar siete variables que se fusionaron para producir los mapas de susceptibilidad a inundaciones y deslizamientos de tierra. En segundo lugar, un total de 43 formas de relieve divididas genéticamente en endógenas (tectónicas) y exógenas (fluviales, gravitacionales y glaciales) se cartografiaron para un área de 1560 km². Finalmente, se realizó un mapa de riesgos geomorfológicos con la zonificación de los diferentes niveles de susceptibilidad de deslizamientos e inundaciones. Esta cartografía es importante en términos de evolución geomorfológica, reducción del riesgo de desastres, así como para la planificación del uso del suelo para unos 40000 habitantes. La metodología presentada también se puede aplicar en otros países en desarrollo para diferentes propósitos, como la evolución del paisaje, mapas detallados morfogenéticos, reducción del riesgo de desastres y planificación territorial.

Palabras clave: geomorfología, amenazas naturales, geomorfometría, cartografía geomorfológica, reducción del riesgo de desastres.

\section{Introduction}

Hydrometeorological disasters number in Costa Rica have been growing during the last decades (Campos-Durán and Quesada-Román, 2017a); especially annual floods and landslides in both, urban and rural areas (Quesada-Román \& Calderón, 2018). This trend is consistent in Central America, a region commonly affected by tropical cyclones due to its position and high vulnerability (CamposDurán and Quesada-Román, 2017b). Recent disaster impacts in Costa Rica, due to the tropical cyclones, are clear examples of the increasing vulnerability. The cost of recovery from Hurricane Otto (2016) signified $0.3 \%$ of the national Gross Domestic Product (GDP), while tropical storm Nate (2017) summed $1.2 \%$ of the GDP (Quesada-Román et al., 2019).

The impacts of natural disasters are mainly in road infrastructure (bridges and roads) where Costa Rica has a clear progress delay, but sometimes with casualties (Brenes and Girot 2018; Quesada-Román et al., 2020a). Furthermore, an increase of heavy rains is predicted for future decades in the Caribbean of Costa Rica (Imbach et al., 2018), and a greater number of tropical cyclone 
occurrence in the Atlantic catchment have been forecast (Lavender et al., 2018), as well as more major hurricanes recurrence (Bender et al., 2010). Concordantly, global tendencies indicate that disaster risk have been exacerbated by climate change increasing its frequency and intensity (UNDRR, 2019). Developing countries and smaller economies, challenge a more difficult economic situation after a comparable disaster than do developed countries or bigger economies (Klomp and Valckx, 2014).

Baseline information in order to reduce disasters in Costa Rica should be enhanced and the cartography of natural hazards must be improved (QuesadaRomán, 2017). However, the number of investigations on vulnerability and risk in the country should increase in order to reduce disasters (Quesada-Román et al., 2018). The increasing vulnerability conditions in Costa Rica due to the inefficient territorial management leads to the occurrence of cascading disasters (Quesada-Román, 2015; Quesada-Román et al., 2020d). Therefore, this study aim to (i) generate a geomorphometric analysis, (ii) a morphogenetic mapping, and (iii) a hazard zonation mapping for landslides and floods for the Upper General River Catchment in southeast Costa Rica, as a study case of detailed geomorphological mapping in tropical dynamic catchments.

\section{Geographical setting}

The UGRC is located $80 \mathrm{~km}$ southeast of the capital of Costa Rica, San José, where the city of San Isidro del General is the most important town. This is where the Cordillera de Talamanca, the General River valley, and the Fila Brunqueña merge in an area of 1,560 km² (Figure 1). The topography and geomorphology of the UGRC results from a complex tectonic interaction between the Cocos, Caribbean, Panama, and Nazca plates, as well as the subduction of the submarine volcanic cordillera of Cocos, also known as the Coco's Ridge, which stopped the volcanism and provoked an intense uplift of Cordillera de Talamanca (DeMets et al., 2010). The study area is divided into two morphotectonic sectors, the fore arc (sedimentary catchments of the General River and Fila Brunqueña) and the inner arc (Cordillera de Talamanca) (Marshall, 2007). The Cordillera de Talamanca is composed of volcanic rocks of the Miocene, while the Fila Brunqueña are made up of sedimentary Oligocene-Miocene rocks (Denyer and Alvarado, 2007).

The latitudinal migration of the Intertropical Convergence Zone (ITCZ), the El Niño Southern Oscillation (ENSO), northeast trade winds, cold fronts, and tropical cyclones influence the local climate and precipitation patterns (QuesadaRomán, 2016). Annual rainfall totals typically reach 3000-5000 mm in the region with two distinct rainfall maxima, one in May and a second, more distinct rainfall peak in October. In July and August, rainfall decreases during two to four weeks, known as the Mid-Summer Drought (Quesada-Román, 2017). About 85\% of the annual rainfall occurs between May and November (rainy season) with a distinct dry season from December to April. Annual average temperatures range between 18 and $22^{\circ} \mathrm{C}$ at the study site. Vegetation is composed mostly 
of páramo over 3000 m (Esquivel-Hernández et al., 2019; Quesada-Román et al., 2020b), tropical premontane, and tropical basal rainforests (Kappelle, 2016). The UGRC have been impacted by earthquakes such Buenavista earthquake (1983), and different tropical cyclones such as Hurricanes Joan (1988), César (1996), Tropical Storm Alma (2008), Hurricane Nate (2017), and Hurricane Eta (2020).

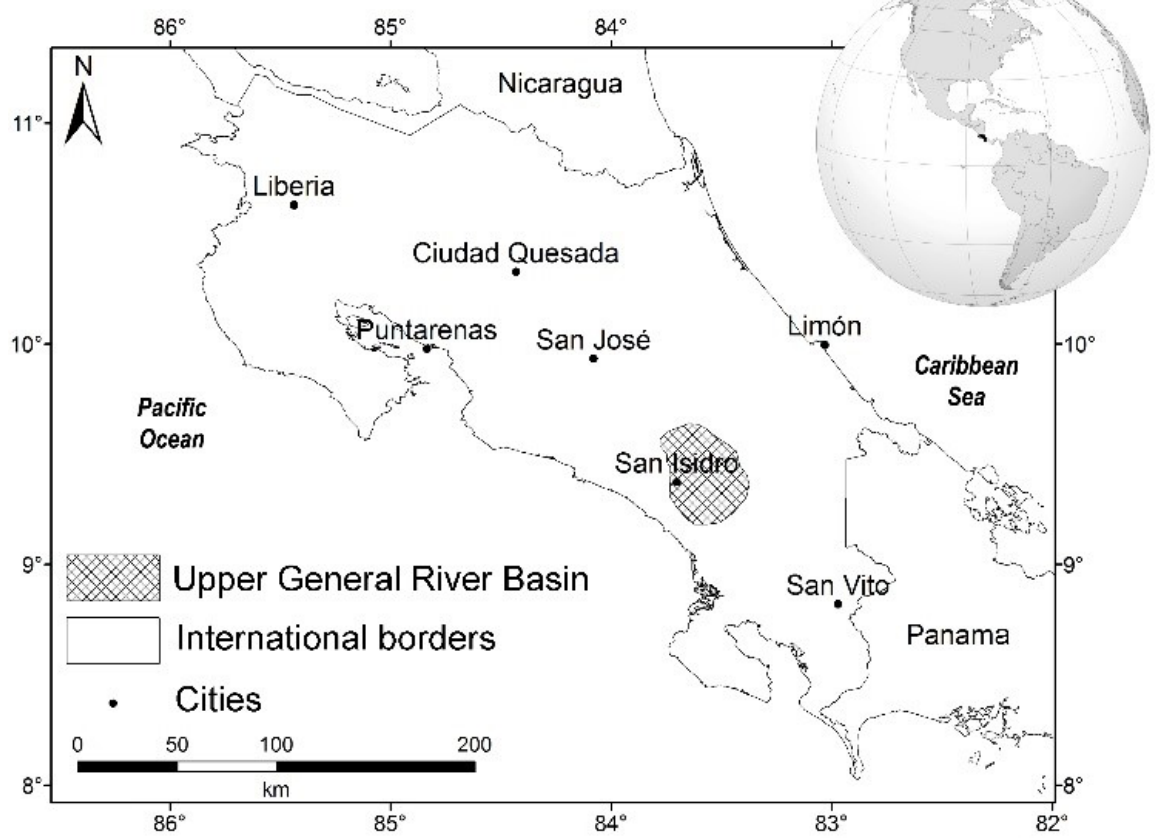

Figure 1. Upper General River Catchment location.

\section{Materials and methods}

This study was conducted in three phases: pre-mapping, fieldwork and postmapping (Smith et al., 2011). During the pre-mapping the geomorphometry and the morphogenetic maps were generated based upon Aerial Photo Interpretation at 1:25,000 scale (CARTA, 2005). These aerial photographs were georeferenced and processed to accomplish the geomorphological mapping (Smith et al., 2011). These aerial photographs were the best input available covering the whole study area, and the morphogenetic do not change during the time. A morphometric analysis calculated and analyzed seven variables (altimetry, slopes, dissection density, dissection profundity, relief energy, potential erosion, and total erosion). These variables were merged in order to 
produce the flood and landslides susceptibility maps, grouped into three ranges (high, medium and low), which allowed a cross analysis with the DesInventar disaster database (LA RED, 2016). This study used the most recent flood and landslide records based on the Des-Inventar disaster database to provide an updated view of the problem.

The fieldwork was conducted during several fieldworks between 2011 and 2013 to check the different landform dynamics and limits using a preliminary morphogenetic map and morphometric cartography at 1:25,000 scale. Due to the geomorphology principal landforms slow change, this study has focused on dynamic landslides and floods prone areas changes. During the post-mapping, the legend for the geomorphological map of the UGRC was prepared, dividing the landforms genetically into endogenic (tectonic) and exogenic (fluvial, gravitational, and glacial), as well as depositional and erosional. Finally, the geomorphometric and morphogenetic maps were created within a Geographic Information System (ArcGIS 10.3). Once morphogenetic and geomorphometry maps are done, a merge of both cartographies is necessary to produce the geomorphological hazards map for landslides and floods zonation. These hazard zones were visited and identified in the field. Due to the large dimensions of the morphogenetic map $(2.6 \times 2.6 \mathrm{~m})$ and the geomorphological hazards maps, these documents can be displayed in high definition in Quesada-Román (2016) and Quesada-Román and Zamorano-Orozco (2019a).

\section{Results and discussion}

\subsection{Geomorphometry analysis}

Five morphological regions were determined: mountain zone (Cordillera de Talamanca), floodplain, accumulative ramp (alluvial fans), minor mountain ranges (Fila Brunqueña), and mountain foothills covered by proluvial sediments (Quesada-Román and Zamorano-Orozco, 2019b). The mountain zone is intensely modeled with the presence of extensive weathering crusts on inclined and fractured slopes, which favors fluvial-gravitational processes. The minor mountain ranges serve as limit to the alluvial plain of the Pacuar and General River, that due to its sedimentary lithology, steep slopes, the rainfall regime and land use changes have trigger its slope instability. The mountain foothills have a plateau morphology with alluvial covers on the base of the slopes. The accumulative proluvial ramp is the transition between the mountain zone and the floodplain, its morphology is defined by the presence of an alluvial fans sequence. Finally, the floodplain is well-defined by the seasonal and extraordinary flooding areas.

The slopes map was the first approximation of the gravitational dynamics. It helped to identify landforms associated with the fluvial erosive-accumulative action. The dissection density showed zones of greater/lesser erosion, where the channels concentration are linked to rainy zones, unconsolidated and 
altered sediments, disjunctive structures, large areas without significant lithological changes, and heterogeneous morphology. Otherwise, the dissection profundity made evident the influence of the disjunctive structures in the erosive and accumulative relief dynamics. The relief energy integrated fluvial action (dissection density and dissection profundity) and slopes in its analysis. These three elements are closely linked to mass wasting. It also considers lithology, the influence of weathering, the faults activity, earthquakes, and precipitation. Else, potential erosion located indirectly areas with denudation susceptibility, linked to factors such as specific lithological characteristics, topographic contrasts, morphological variety, hydroclimatic conditions, vegetation cover, and land use changes. In the case of total erosion, areas with greater erodibility and with older morphologies were distinguished through the terrain roughness, and the role played by variables such as lithology age, disjunctive structures, the past climate (glaciations), the current rainfall patterns, and slopes.

The territories where up to two morphometric indicators coincided, were considered as potential areas; the areas where three indexes were overcome, were classified as frequent occurrence areas, and the spaces classified as maximum occurrence were those where four or five variables matched. These criteria were applied for landslides and floods. These maps are spatially compared with the disaster database DesInventar (LA RED, 2016), where $85.15 \%$ of the reports coincide with the zones identified as prone to flooding and $76.54 \%$ with susceptible areas to landslides (Figure 2).

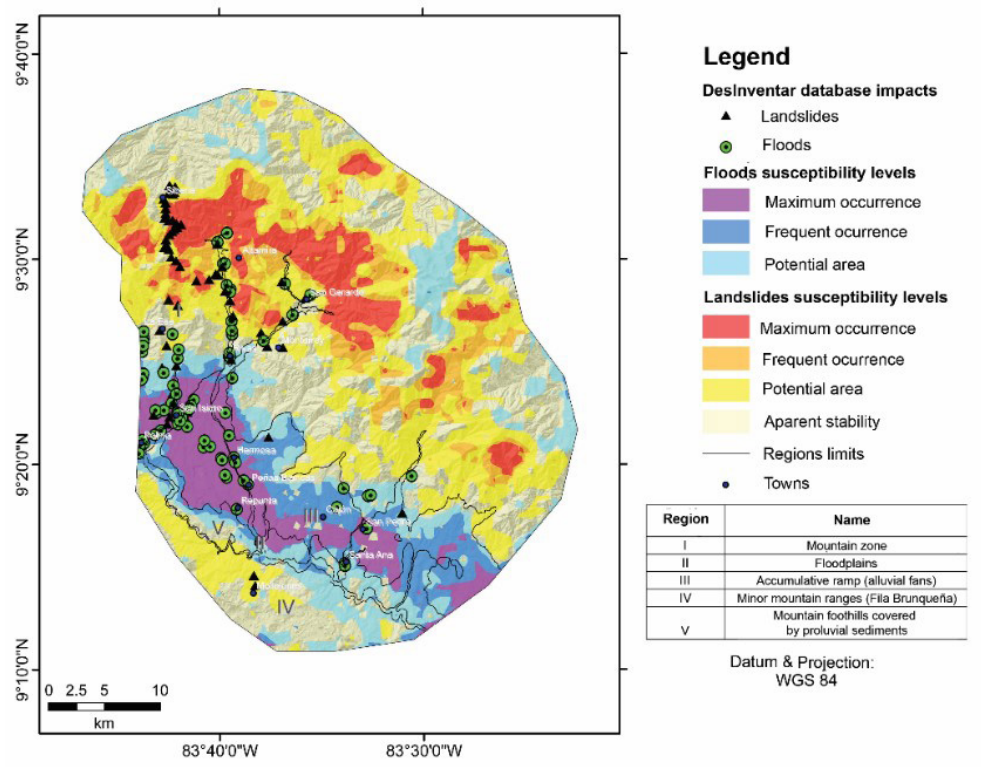

Figure 2. Geomorphometry landslides and floods susceptibility zonation. 


\subsection{Morphogenetic mapping}

According to Quesada-Román (2016) and Quesada-Román and Zamorano (2019a), the morphogenetic classification presented 46 landforms, organized in endogenic landforms (tectonic) and exogenic (fluvial, gravitational, and glacial). The endogenic landforms comprise uniquely tectonic landforms associated with a strike-slip fault identified in the SE of the study area that comprise the spatial distribution, arrangement, variety, and morphology of escarpments, fluvial deflections, shutter ridges, and sag ponds (Quesada-Román and Zamorano, 2019a).

The exogenic landforms are divided in fluvial, gravitational and glacial genesis. The erosive fluvial landforms are the result of the action of the rivers, which when acting in conjunction with the gravitational movements form valleys, which are not isolated structures, are linked with other fluvial forms, both erosive and accumulative such as cirques, headwaters, ravines and gullies. The depositional fluvial landforms begin to appear at the moment in which the longitudinal profile of the river decreases its slope and is associated with alluvial fans, floodplains, flood terraces, and alluvial cones.

Alluvial fans origin and evolution are directly conditioned by tectonics and climate. The first variant is linked to the rise of the source area, the Cordillera de Talamanca. Its lift has been calculated at $1.1 \mathrm{~mm}$ per year and has been constant in the last 2 Ma (Gardner et al., 2013). This condition added to the wide and dense channel network has favored intense erosion and with it, the transport and accumulation of important detrital deposits south of the most important mountain chain in the country. Otherwise, the influence of the climate is evident from $3000 \mathrm{~m}$ asl, the region was under colder conditions from 100 to $10 \mathrm{ka}$ ago (Orvis \& Horn, 2000). The existence of landforms of glacial origin (geomorphological inheritances) made up of debris, left at the disposal of river erosion and transport the sediments mobilization through the glacial and fluvial valleys. Most of these materials became part of extensive fans on the periphery of the mountain. In general, they maintain an inclination $<10^{\circ}$, and the orientation of the longest distance, to the SW, and were classified according to their relative height in late, intermediate, and early (Camacho et al., 2020).

The floodplains occupy the bottom of wide valleys, which in most cases are flooded areas during the rainy season or in extraordinary rainfall periods (tropical cyclones) that were classified as intermountain, transitional (between alluvial fans) and wide areas: Pacuar and General rivers. The floodplains alternate with flood terraces that are characterized by being symmetrical and asymmetric, three levels of terraces are recognized: seasonal, extraordinary and exceptional. These characteristics reveal a lateral and vertical erosive dynamic associated with intense neotectonics movements (Quesada-Román, 2017). The gravitational landforms are located on slopes greater than $15^{\circ}$ and where the substrate is poorly consolidated (fractured and weathered rocks, debris or soil), the presence of disjunctive struc-tures favors its development, 
and the precipitation magnifies its dynamic ( $>2,500 \mathrm{~mm}$ annually). The mass movements cirques are associated with landslides, rockfalls, and mudflows with step and lobular morphologies (Quesada-Román et al., 2018).

Glacial morphologies are landforms originated during the Last Glacial Maximum (Quesada-Román et al., 2019b). These paleoforms were formed as a result of the accumulation of snow and ice, resulting in processes of abrasion and polishing due to the downslope movement of the glacial ice masses. Among the erosional glacial landforms, volcanic slopes modified by glacial action, cirques, arêtes, riegels, glacial lakes, and rôches moutonnées. The volcanic slopes modified by glacial action are located over $3000 \mathrm{~m}$ in altitude, they were shaped by the colder conditions during the LGM (Quesada-Román et al., 2020c). Here, straight and concave geometries predominate among the exhumation of polished, predominantly granodiorite rocks. The most representative depositional glacial landforms are the lateral and ground moraines which show the extent of glacial advances during the LGM. On these landforms rely 963 palustrine and lacustrine wetlands with a para-mount hydrological and ecological importance (Veas et al., 2018; Esquivel-Hernández et al., 2018).

\subsubsection{Geomorphological hazards map: landslides and floods zonation}

\subsubsection{Landslides susceptible territories}

The maximum occurrence sites for landslides are located on slopes greater than $25^{\circ}$ where the typical geological outcrops are from Miocene volcanic and plutonic rocks in concave and straight slopes (Figure 3a). The highest values recorded in dissection density, relief energy, depth of dissection, potential and total erosion morphometric variables showed regions of strong slope instability (Quesada-Román et al., 2018). Maximum occurrence to landslides are activated by well-identified triggering agents such as highly weathered substrates, seasonal (> $2500 \mathrm{~mm}$ annually) and cyclonic rains (between August and November), and the seismic-tectonic influence (Figure 4). The low-occurrence landslides territories are defined as extensive areas that encapsulate the regions of maximum occurrence with intense instability on mountain slopes where concave and straight morphologies predominate with inclinations between 16 and $63^{\circ}$, located on Miocene granite rock substrates. The potential areas for landslides are located on straight and concave mountain slopes less than $25^{\circ}$, on Miocene volcanic, plutonic and sedimentary substrates. The territories with apparent stability to landslides are located in middle or low ranges (less than $25^{\circ}$ ) with a dense forest coverage. 

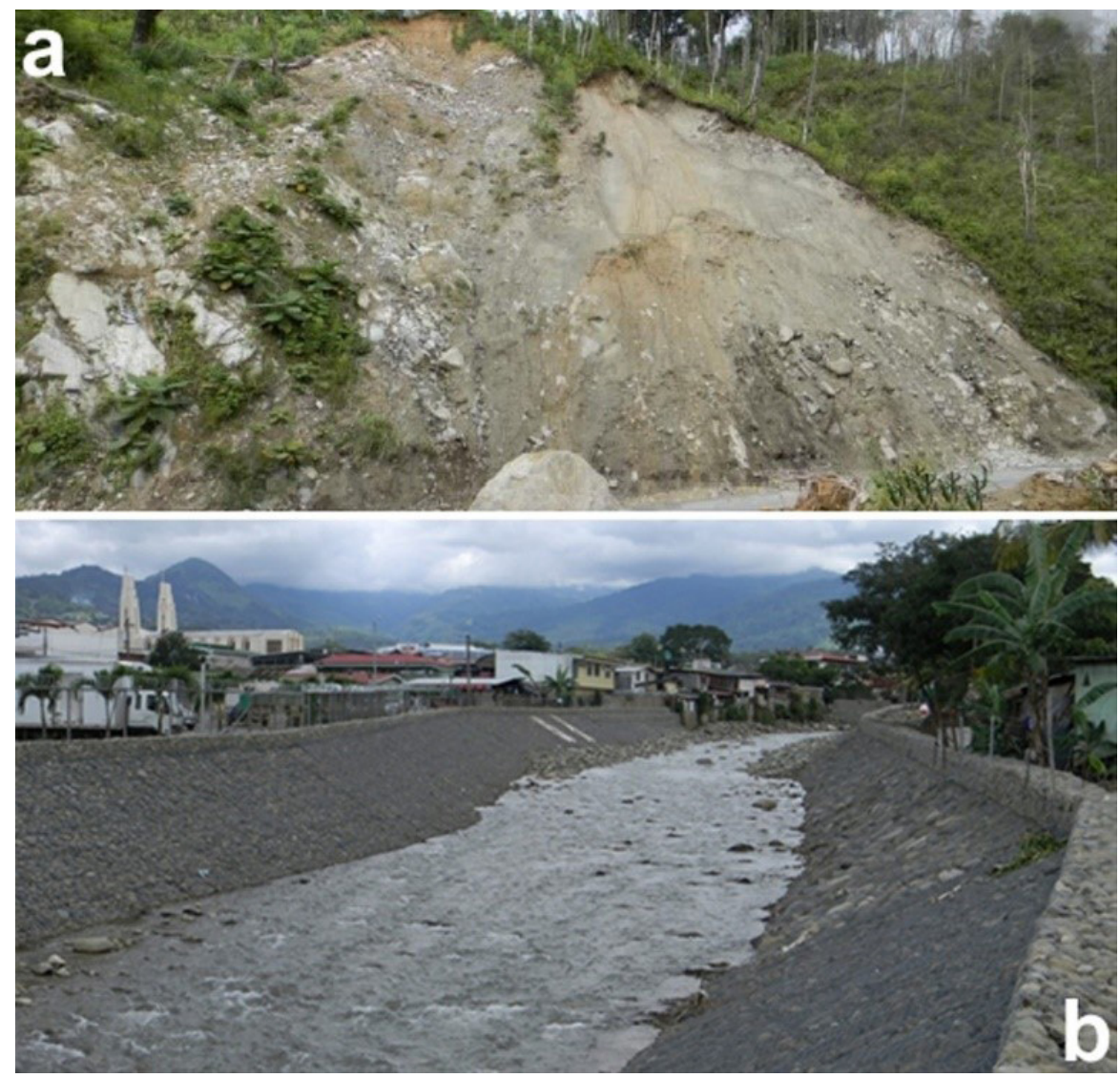

Figure 3. (a) Maximum occurrence landslide over Interamerican Highway. (b) Apparent seasonal flood bed in San Isidro del General. 


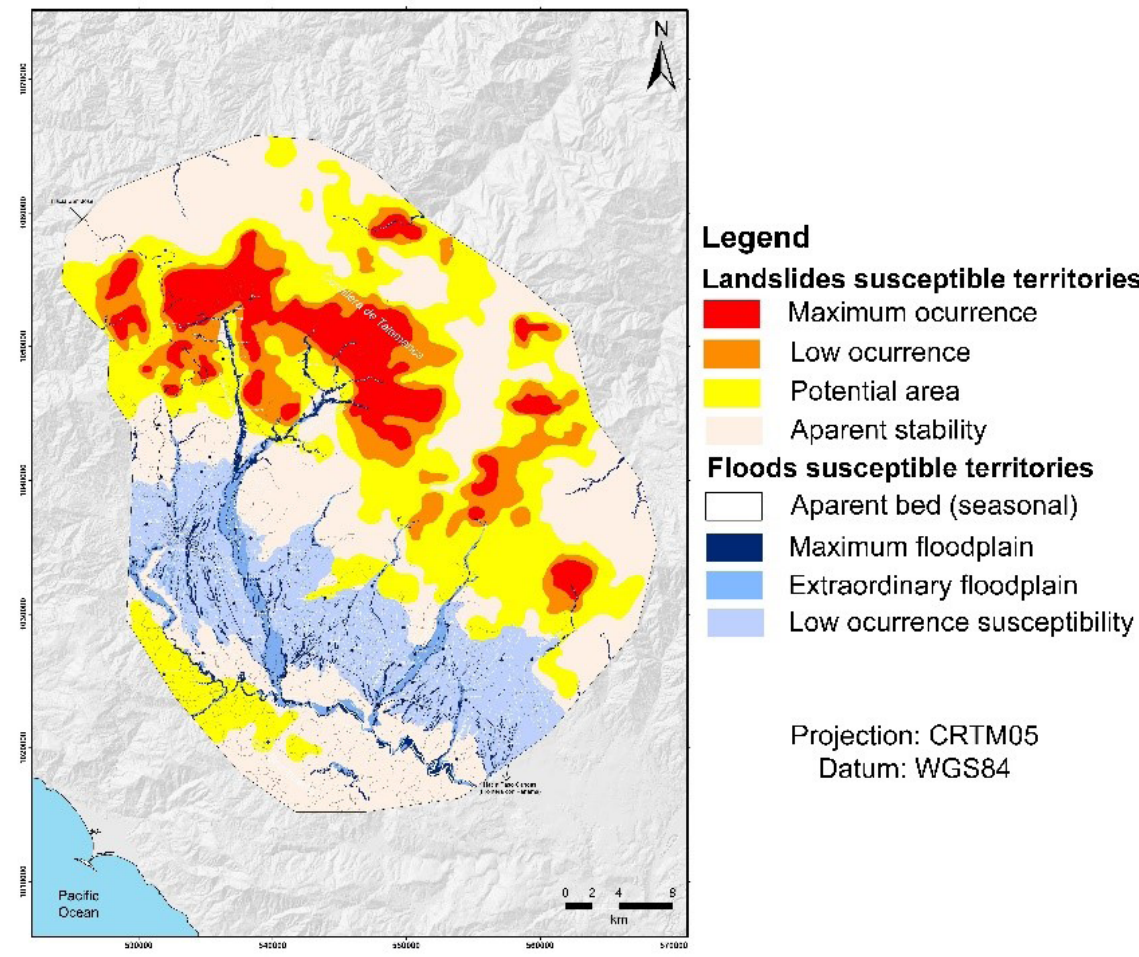

Figure 4. Geomorphological hazards (landslides and floods) zonation.

\subsubsection{Floods susceptible territories}

The apparent (seasonal) beds are located in the lower sections of rivers such as the Buenavista, Chirripó Pacífico, Pacuar, San Pedro, Convento and General, where flooding and overflow processes occur each year during the rainy season between May and November (Figure 3b). Maximum floodplains are terrains with low inclinations $\left(<15^{\circ}\right.$ ) and subhorizontal morphology (Quesada-Román and Zamorano-Orozco, 2018). To this condition is added that in rainy seasons the soils are saturated, which helps the overflow of channels. Floods occur once the rainy seasons exceed the annual average, or are influenced by low pressure systems, temporary or both direct and indirect effects of tropical cyclones with a recurrence of less than 5 years. The maximum floodplains are associated with subhorizontal morphologies with inclinations less than $15^{\circ}$ that are within the floodplains (Figure 4). These regions are activated during extraordinary rainy seasons in conjunction with extreme events such as the La Niña phenomenon, the atmospheric anomalies associated with the Intertropical Convergence Zone and the tropical cyclones of the Caribbean Sea and the Pacific Ocean (Alfaro 
\& Quesada-Román, 2010). The areas with floods low occurrence are made up of sections that do not belong to the flood plains with slopes below $15^{\circ}$ and $a$ significant fluvial density (Figure 4).

\section{Conclusions}

Geomorphometry is a practical tool for disaster risk mitigation to determine susceptible floods and landslides areas. However, it requires a correction with the landforms to specify the areas to be affected from a more accurate mapping. These procedures can be baseline assessments for the territorial management of hydrographic catchments and political-administrative units at local and regional scales.

The conditions that favor the physical vulnerability of the study area are recognized in the floodplains of the General River where floods are frequent and are associated with intense rains, both seasonal like tropical cyclones. Landslides are frequent in the mountain area where the slope of the terrain exceeds $25^{\circ}$. The most important disasters were the Buenavista earthquake (1983), Hurricanes Joan (1988), César (1996), Tropical Storm Alma (2008), Tropical Storm Nate (2017) and Hurricane Eta (2020). These disasters brought deaths and serious economic losses on vital lines (communication routes, electrical wiring and aqueducts) as well as in the agricultural sector.

From morphometric and morphogenetic cartography integration, a geomorphological hazard map was made, which allowed determining areas with different levels of susceptibility to landslides and floods. The landslides presented the following susceptibility classes: maximum occurrence, low occurrence, and potential area. While, for floods: apparent bed (seasonal), maximum floodplain, extraordinary floodplain, and low susceptibility to occurrence. These territories help to delimit, with a very detailed scale, the regions exposed to these common natural risks that could generate economic losses in the UGRC. This methodology can also be used for other areas of Costa Rica as well as other tropical and developing countries for different purposes, including the landscape evolution, morphogenetic detailed maps, disaster risk reduction, and land use planning.

\section{References}

Alfaro, E., Quesada-Román, A., \& Solano, F. J. (2010). Análisis del impacto en Costa Rica de los ciclones tropicales ocurridos en el Mar Caribe desde 1968 al 2007. Revista Diálogos, 11(2), 25-38. https://doi.org/10.15517/dre.v11i2.578

Bender, M. A., Knutson, T. R., Tuleya, R. E., Sirutis, J. J., Vecchi, G. A., Garner, S. T., \& Held, I. M. (2010). Modeled impact of anthropogenic warming on the frequency of intense Atlantic hurricanes. Science, 327, 454-458. https://doi.org/10.1126/science.1180568 
Brenes, A., \& Girot, P. (2018). Gestión del riesgo y cambio climático. Informe Estado de la Nación en Desarrollo Humano Sostenible. Pavas, Costa Rica: CONARE, Programa Estado de la Nación, pp. 1-52.

Camacho, M. E., Quesada-Román, A., Mata, R., \& Alvarado, A. (2020). Soil-geomorphology relationships of alluvial fans in Costa Rica. Geoderma Regional, 21, e00258. https://doi.org/10.1016/j.geodrs.2020.e00258

Campos-Durán, D., \& Quesada-Román, A. (2017a). Impacto de los eventos hidrometeorológicos en Costa Rica, periodo 2000-2015. Revista Geo UERJ, 30, 440-465. https://doi.org/10.12957/geouerj.2017.26116

Campos-Durán, D., \& Quesada-Román, A. (2017b). Riesgos Intensivos y Extensivos en América Central entre 1990 y 2015. Anuário do Instituto de Geociências, 40(2), 234-249. http://dx.doi.org/10.11137/2017_2_234_249

CARTA - Costa Rica Airborne Research and Technology Applications. (2005). Aerial photographs scale 1:25,000 of Costa Rica. NASA (USA) and Costa Rica Government.

DeMets, C., Gordon, R. G., \& Argus, D. F. (2010). Geologically current plate motions. Geophysical Journal International, 181(1), 1-80. doi:10.1111/j.1365-246X.2009.04491.x.

Denyer, P. \& Alvarado G. E. (2007). Mapa geológico de Costa Rica. San José, Costa Rica: Librería Francesa. Escala 1:400 000.

Esquivel-Hernández, G., Sánchez-Murillo, R., Quesada-Román, A., Mosquera, G.M., Birkel, C., \& Boll, J. (2018). Insight into the stable isotopic composition of glacial lakes in a tropical alpine ecosystem: Chirripó, Costa Rica. Hydrological Processes, 32(24), 3588-3603. https://doi.org/10.1002/hyp.13286

Esquivel-Hernández, G., Mosquera, G. M., Sánchez-Murillo, R., Quesada-Román, A., Birkel, C., Crespo, P., Célleri, R., Windhorst, D., Breuer, L., \& Boll, J. (2019). Moisture transport and seasonal variations in the stable isotopic composition of rainfall in Central American and Andean Páramo during El Niño conditions (20152016). Hydrological Processes, 33(13), 1802-1817. https://doi.org/10.1002/hyp.13438

Gardner, T.W., Fisher, D. M., Morell, K. D., \& Cupper, M. L. (2013). Upper-plate deformation in response to flat slab subduction inboard of the aseismic Cocos Ridge, Osa Peninsula, Costa Rica. Lithosphere, 5(3), 247-264. https://doi.org/10.1130/L251.1

Imbach, P., Chou, S. C., Lyra, A., Rodrigues, D., Rodriguez, D., Latinovic, D., Siqueira, G., Silva, A., Garofolo, L., \& Georgiou, S. (2018). Future climate change scenarios in Central America at high spatial resolution. PlosONE, 13(4), 1-21. https://doi.org/10.1371/journal. pone.0193570

Klomp, J., \& Valckx, K. (2014). Natural disasters and economic growth: A meta-analysis. Global Environmental Change, 26, 183-195. https://doi.org/10.1016/j.gloenvcha.2014.02.006

Lachniet, M. S., \& Seltzer, G. O. (2002). Late Quaternary glaciation of Costa Rica. Geological Society of America Bulletin, 114, 547-558.

LA RED - Red de Estudios Sociales en Prevención de Desastres en América Latina. (2016). DesInventar: Sistema de inventario de efectos de desastres de Costa Rica entre 1970 y 2015. Ciudad de Panamá, Panamá. 
Lavender, S. L., Walsh, K. J., Caron, L. P., King, M., Monkiewicz, S., Guishard, M., Zhang, Q., \& Hunt, B. (2018). Estimation of the maximum annual number of North Atlantic tropical cyclones using climate models. Science Advances, 4(8), 1-7. https://doi.org/10.1126/sciadv.aat6509

Marshall, J. (2007). The Geomorphology and Physiographic Provinces of Central America. In: Bundschuc \& Alvarado (Eds), Central America: Geology, Resources and hazards. Taylor \& Francis. 1436 pp. https://doi.org/10.1201/9780203947043.pt2

Orvis, K. H., \& Horn, S. P. (2000). Quaternary Glaciers and Climate on Cerro Chirripó, Costa Rica. Quaternary Research, 54(1), 24-37. doi:10.1006/qres.2000.2142

Quesada-Román, A. (2015). Implicaciones en la gestión del riesgo de desastres y ambiente en el Valle Central en los últimos treinta años (1985-2015). Vigesimoprimer Informe Estado de la Nación en Desarrollo Humano Sostenible (2014).

Quesada-Román, A. (2016). Peligros geomorfológicos : inundaciones y procesos de ladera en la cuenca alta del Río General, Pérez Zeledón, Costa Rica. (Tesis de Maestría). Universidad Nacional Autónoma de México, México. Available on https://repositorio.unam.mx/contenidos/83125

Quesada-Román, A. (2017). Geomorfología Fluvial e Inundaciones en la Cuenca Alta del Río General, Costa Rica. Anuário do Instituto de Geociências, 40(2), 278-288. http://dx.doi.org/10.11137/2017_2_278_288

Quesada-Román, A., \& Calderón-Ramírez, G. (2018). Gestión del riesgo y política pública en el cantón de Desamparados, Costa Rica. Uniciencia, 32(2), 1-19. http://dx.doi.org/10.15359/ru.32-2.1

Quesada-Román, A., Ballesteros-Cánovas, J. A., Granados-Bolaños, S., Birkel, C., \& Stoffel, M. (2020a). Dendrogeomorphic reconstruction of floods in a dynamic tropical river. Geomorphology, 359, 107133.

https://doi.org/10.1016/j.geomorph.2020.107133

Quesada-Román, A., Ballesteros-Cánovas, J. A., Guillet, S., Madrigal-González, J, \& Stoffel, M. (2020b). Neotropical Hypericum irazuense shrubs reveal recent ENSO variability in Costa Rican páramo. Dendrochronologia, https://doi.org/10.1016/j.dendro.2020.125704

Quesada-Román, A., Campos, N., Alcalá-Reygosa, J., \& Granados-Bolaños, S. (2020c). Equilibrium-line altitude and temperature reconstructions during the Last Glacial Maximum in Chirripó National Park, Costa Rica.Journal of South American Earth Sciences, 100, 102576. https://doi.org/10.1016/j.jsames.2020.102576

Quesada-Román, A., Fallas-López, B., Hernández-Espinoza, K., Stoffel, M., BallesterosCánovas, J.A. (2019). Relationships between earthquakes, hurricanes, and landslides in Costa Rica. Landslides, 16(8), 1539-1550.

https://doi.org/10.1007/s10346-019-01209-4

Quesada-Román, A., Moncada-López, R., Paz-Tenorio, J.A., Espinoza-Jaime, E., CastellónMeyrat, C., \& Acosta-Galeano, N. (2018). Las investigaciones sobre movimientos de laderas en Costa Rica, Honduras, México y Nicaragua: enseñanzas desde la academia, las agencias de cooperación y las instituciones públicas. Revista Geográfica de América Central, 60, 17-59. http://dx.doi.org/10.15359/rgac.60-1.1

Quesada-Román, A., Stoffel, M., Ballesteros-Cánovas, J. A. \& Zamorano-Orozco, J. J. (2019b). Glacial geomorphology of the Chirripó National Park, Costa Rica. Journal of Maps, 15(2), 538-545. https://doi.org/10.1080/17445647.2019.1625822 
Quesada-Román, A., Villalobos-Portilla, E., \& Campos-Durán, D. (2020d). Hydrometeorological disasters in urban areas of Costa Rica, Central America. Environmental Hazards (in press).

Quesada-Román, A., \& Zamorano-Orozco, J. J. (2018). Peligros Geomorfológicos en Costa Rica: Cuenca Alta del Río General. Anuário do Instituto de Geociências, 41(3), 239-251. http://dx.doi.org/10.11137/2018_3_239_251

Quesada-Román, A., \& Zamorano-Orozco, J. J. (2019a). Geomorphology of the Upper General River Basin, Costa Rica. Journal of Maps, 15(2), 95-101. https://doi.org/10.1080/17445647.2018.1548384

Quesada-Román, A., \& Zamorano-Orozco, J. J. (2019b). Zonificación de procesos de ladera e inundaciones a partir de un análisis morfométrico en la cuenca alta del río General, Costa Rica. Investigaciones Geográficas, 99, e59843. http://dx.doi.org/10.14350/rig.59843

Smith, M. J., Paron, P., \& Griffiths, J. S. (2011). Geomorphological mapping: Methods and Applications. (Vol. 15). Elsevier. pp. 612.

UNDRR - United Nations Office for Disaster Risk Reduction. (2019). Global Assessment Report on Disaster Risk Reduction. Geneva, Switzerland.

Veas-Ayala, N., Quesada-Román, A., Hidalgo, H., \& Alfaro, E. (2018). Humedales del Parque Nacional Chirripó, Costa Rica: características, relaciones geomorfológicas y escenarios de cambio climático. Revista de Biología Tropical, 66(4), 1436-1448. https://doi.org/10.15517/rbt.v66i4.31477 